\title{
The Relationship Between Aristotle and Alexander the Great
}

\author{
Yuchen $\mathrm{Wu}^{*}$ \\ Nanjing Foreign Languages school, Nanjing, Jiangsu 210008, China \\ *Corresponding author. Email: 2947942209@qq.com
}

\begin{abstract}
Aristotle and Alexander the Great, two outstanding characters in history bearing idiosyncratic personalities and outlooks, are not only teacher and student, but also destined friends and rivals. They were born in the era when Greek civilization faced a portent from rotating greatly declining, and when a variety of major changes took place in Greek city states, Macedonia and Persia. Aristotle and Alexander exerted a far-reaching impact on the continuation of the territory. This paper illustrates the life-long influence that Aristotle exerted on Alexander, and puts forward their contradictory attitudes in different realms, including military affairs, political perspectives, and sets of values. The origin of their disparity is explored, and the incentives of Alexanders' innovations are illustrated. Alexander, an ambitious and unconventional student, inherited some of his teacher's thoughts and ingeniously evolved novel aspects.
\end{abstract}

Keywords: Alexander the Great, Aristotle's philosophy, Eastern expedition of Alexander, Structure of city states, Ancient cultural integration

\section{INTRODUCTION}

In the endless torrent of history, there are countless well-known teacher-student relationships. Yan Hui learned from Confucius and epitomized the thought of past and presence; Plato debated the nature of akrasia with Socrates and created Timaeus; Aristotle stated that 'Plato is dear to me, but dearer still is truth'... Among all these paragons, people should never overlook the relationship between Aristotle and Alexander the Great, one with mystic and labyrinthine tint.

Scholars have raised hot debates about the relationship between Aristotle and Alexander. Plutarch, Arrian and Justin all meticulously recorded Aristotle's role throughout Alexander's life. Hegel thought that Alexander's career showed the practical usefulness of philosophy taught by Aristotle, while Russel believed that Aristotle's impact was nil. This paper evaluates Aristotle's influence on Alexander from his early education to later conquest and analyzes their similarities and differences.

\section{THE EARLY INFLUENCE THAT ARISTOTLE EXERTED ON ALEXANDER}

In BC 343, when Alexander was thirteen years old,
Philip brought the famous philosopher Aristotle to Pella to serve as Alexander's tutor, who taught Alexander in ethics, politics, and eristics [1]. It was during such period that Alexander obtained significant theoretical foundation of his later conquest of the world.

\subsection{Empiricism of Aristotle and Alexander}

Aristotle taught his students what predecessors thought and how they acted. This is history-the information on the vertical axis. For instance, he brought Iliad to Alexander, a book that played an indispensable role throughout his life. (This book will be elaborated on later.) He took with him Aristotle's recension of the poem, called the Iliad of the Casket, and always kept it lying with his dagger under his pillow. Alexander inherited his teacher's all-inclusive interest and the corresponding strong empiricism. But he owned a database disparate from that of Aristotle's, for he was living and acting in the practical world of warfare and governance.

\subsection{Science and nature}

Aristotle also taught him about scientific and natural matters - the information on the horizontal axis. For 
instance, he manifestly inculcated the art of healing in Alexander, and Alexander applied such knowledge to cure his friends, putting conceptions into practice. He benefited from this kind of scientific education and developed a keen and flexible mind, fortifying his ability to deal with problems without prejudice.

\subsection{Observation}

Another invaluable quality that Aristotle rendered Alexander was good powers of observation and insightfulness. Ever since Alexander was a little boy, Aristotle incessantly infuse the importance of observation to Alexander. He asked him to pay careful attention to every detail beside him. Once, Philoneicus brought about a savage and intractable horse called Bucephalas to Philip, but nobody was able to tame it. At that time, Alexander stood out and boldly pledged that he could successfully manage Bucephalas. When other people were perplexed by the superficial appearance, Alexander used his penetrating eyes to find that the horse was actually afraid of his own shadow. As a result, he took hold of the bridle-rein, and turned Bucephalas towards the sun. Then he calmed the horse, stroked it with his hand, and at last urged it on with sterner tone and thrust of foot. Alexander, with superb ability of observation taught by Aristotle, became the only one to tame Bucephalas, which later became his beloved horse and accompanied him for countless significant battles.

\subsection{Arts Liberales}

This comprehensive education of history, science, nature and society was just like what the Romans later called "Arts Liberales", or "liberal arts" in English. It was this kind of logical thinking and prudent judgement brought about by Aristotle that marked Alexander's most distinctive qualities as a battlefield commander. Young Alexander was so fortunate that he possessed the opportunity to enjoy superior level of education from the most eminent instructor at the age of 13 to 16 , the most appropriate time to absorb knowledge.

\subsection{Iliad}

\subsubsection{Military art}

Now, back to the topic of Iliad. Thanks to Aristotle's introduction, this book opened up a new vista for Alexander. He regarded this book as a viaticum of the military art, containing various methods of military use and bringing him infinite courage. For instance, after defeating Darius, Alexander continued to march towards the coast and gave siege to Gaza adjacent to the Mediterranean Sea. After conquering Gaza, he killed the incompetent leader Batis and dragged his body around the city. This rather ferocious behavior obviously paid tribute to the plot in the Iliad, where Achilles killed Hector and circled the city. But Batis, evidently, was not the "Hector" in Alexander's mind, while the true 'Hector' to him was the shrewder and more scheming Darius.

\subsubsection{Integrated culture}

Iliad also changed Alexander's attitude towards the culture of the conquered areas in the future eastern expedition, and making Alexander endeavor to promote Greek culture to the conquered areas. Alexander indulged his desire of emulating the Median and Persian wealth, changing the Macedonian style of dress to a Median one [2]. He also adopted the custom of Proskynesis, which irritated many of his subjects. In addition, his first marriage was with an Asian girl, Roxane, causing many Macedonians indignant and infuriated. There, to subside Macedonians' wrath, Alexander used the plot in Iliad that Achilles had an Asian girlfriend to justify his marriage. These examples all showed how profoundly has Iliad influenced Alexander.

\subsubsection{Motivation to fight}

A lot of role models of Alexander were from Iliad. He wanted to liberate people all over the world and surpass the glory of Achilles and Heracles, desiring to save the whole mankind like Prometheus. He especially admired Achilles' braveness and virtually invincible army. When he passed through Troy in the eastern expedition, Alexander paid a visit to the gravestone of Achilles and commemorated him. When being asked if he wished to see the lyre of Paris, Alexander composedly said that 'I care very little, but I would gladly see that of Achilles, to which he used to sing the glorious deeds of brave men.' There is no doubt that Achilles, brought about by Aristotle, played a paramount role throughout Alexander's life. Alexander invariably expected to become a hero like Achilles, establish such great achievements, and even surpass Achilles. This motivation and determination stimulated him to accomplish successive battles and continue his conquest.

\section{THE LATER DEVELOPED DIFFERENCES BETWEEN ALEXANDER AND ARISTOTLE}

There is no doubt that Alexander deeply admired Aristotle at first: as he himself used to say, more than he did his father. Nevertheless, as he grew older and experienced more incidents, he held Aristotle in more or less of suspicion. His kindly attentions lacked their former ardor and affection towards him, and this was proof of estrangement [3]. Both of them owned peculiar merits and deficiencies, which deserves insightful 
researches. The following paragraphs elaborate on their differences in various realms. Table 1 is shown to generalize their discrepancies.

Table 1 The difference between Aristotle and Alexander

\begin{tabular}{|l|l|l|}
\hline & Aristotle & $\begin{array}{l}\text { Alexander the } \\
\text { great }\end{array}$ \\
\hline $\begin{array}{l}\text { Definition of } \\
\text { braveness }\end{array}$ & $\begin{array}{l}x \quad \text { Pure } \\
\text { passiong } \\
\times \text { Sanguine } \\
\text { x lgnorance } \\
\text { of hazard }\end{array}$ & $\begin{array}{l}\text { passion } \\
\text { V Sanguine } \\
\text { V lgnorance } \\
\text { of hazard }\end{array}$ \\
\hline City States & $\begin{array}{l}\text { Small } \\
\text { population= } \\
\text { high quality }\end{array}$ & $\begin{array}{l}\text { Large scale; } \\
\text { Reforms: } \\
\text { military, } \\
\text { culture, } \\
\text { politics, } \\
\text { diplomacy }\end{array}$ \\
\hline $\begin{array}{l}\text { Conquered } \\
\text { people }\end{array}$ & $\begin{array}{l}\text { Barbarians; } \\
\text { Treated like } \\
\text { plants and } \\
\text { animals }\end{array}$ & $\begin{array}{l}\text { Reverence; } \\
\text { Integration }\end{array}$ \\
\hline
\end{tabular}

\subsection{Different definition of braveness and different outlook}

Although Alexander and Aristotle both attached much importance to braveness, they held different beliefs about it. To begin with, from Aristotle's point of view, pure passion was not true courage. In his book The Nicomachean Ethics, he mentioned that blinded passionate people are not brave because, driven by pain and passion, they rush on danger without foreseeing any perils, and he emphasized that rational choice and motive should be added [4]. He also believed that sanguine people are not brave, for they are confident because they have conquered often and against many foes. In addition, he maintained that people who are ignorant of hazard are not brave, since as soon as they know they are different from what they supposed, they are no longer bold any more, as happened to the Argives when they fell in with the Spartans and took them for Sicyonians.

Alexander, however, held an inconsistent view and believed that these kinds of people are indeed brave and deserved compliment and reverence. For instance, after the siege of Thebes, some Thracians broke into the house of Timocleia, plundering her property and violating her. Then she induced the leader to the well and pushed him into it, finally killing him. When she was taken under escort to Alexander, she showed that she was dignified and lofty through her mien and gait, also mentioning that she was a sister of Theagenes, who drew up the forces which fought Philip on behalf of the liberty of the Greeks. Alexander was shocked by her answer and boldness, so he bade her depart in freedom with her children. To him, Theagenes was a respectable character; nevertheless, if people use the standard of Aristotle to evaluate her, it is not difficult to see that Theagenes was somehow excessively sanguine and impulsive, lacking sensibility and deliberation, thus cannot be recognized as brave.

Another example was that he had a fierce battle with Porus, a brave figure with strong constitution and sophisticated army, on the bank of Hydaspes River. Porus was undoubtedly a person who was ignorant of hazard and passionate, against Aristotle's definition of braveness, but Alexander respected him a lot. After Porus was defeated, Alexander asked him how he would be treated, and Porus answered: "Like a king." Accordingly, Alexander not only permitted him to govern his former kingdom, giving him the title of satrap, but also added to it the territory of the independent peoples whom he subdued, including fifteen nations, five thousand cities of considerable size, and a great multitude of villages [2]. Alexander intensely admired this kind of people, and he himself was indeed a typical example of excessive passion, sanguinity, and fearlessness.

\subsection{Different opinions about City States}

Greek city states were often politically independent of each other, although economically they relied on a certain extent of cooperation to ensure that they get what they could not produce alone. Aristotle thought no State should have as many as one hundred thousand citizens, and preached the doctrine of the golden mean. To him, small population guarantees the high quality of a civilization. It was significant that everyone in the community should know each other, so better manipulation could be guaranteed. Aristotle's concept of city-state also contained deep civic prejudice, which completely denied the political rights of slaves, Gentiles and women. Obviously, Aristotle saw slaves as tools and felt it necessary to make a distinction between slaves and free people to maintain life in the city states. Both Plato and Aristotle believed that city states should be independent units. However, individual Greek city states had to depend on each other and on the surrounding world to guarantee further development and fundamental supply.

Alexander only deemed his teacher's brainchild as a platitude from a prosy old pedant. He was never gratified with the originally small states. Instead, he endeavored to continuously enlarge their scale and carried on with his conquest, wishing to prove that they were not barbarians. It was analogous to the feeling of 
nineteenth-century Russian aristocrats for Paris, which could not be ascribed to Aristotle's influence [5]. In decision making, Alexander believed that the whole body of citizens together would have the necessary knowledge in order generally to reach the right decision, even though the individual might not be particularly qualified to decide. Furthermore, he made a series of reforms about the existent States. Militarily, he resorted to force to suppress the unrest and insurrections. His army could both fight in battlefields and work in different sections of the city. Politically, he strengthened the Collins Synedrion to progressively guarantee his predominating right and his govern of the State. Culturally, he emphasized the legitimacy and authenticity of his leadership of the State by expanding the propaganda of Hellenism at many levels, defending his expedition towards Persia. He broadened the horizon of the Greeks and completely changed their value, lifestyle and even philosophy (cynicism and Stoicism came into being at his time). Diplomatically, he obliged the states to participate in invading Persia through treaties. Under his rule, the era of City States undoubtedly gave way to the era of empires.

\subsection{Different attitude towards the foreigners that they have conquered}

From Aristotle's perspective, Greeks can be treated equally and genially as friends, but non-Greeks - barbarians - should be treated like animals or plants [6]. He also mentioned that people whose skin was too dark were cowards, such as Egyptians and Ethiopians; people whose skin was too light were also cowards, which can be seen from women. Only the intermediate ones were notable warriors. This kind of evidence all showed that Aristotle, to some extent, had an inclination of racial discrimination. He deeply deemed that non-Greek ethnic groups are naturally more tolerant of despotism, and they possessed the instinct to become slaves. Ethnocentrism had entrenched in his mind since he was born. In this part, Aristotle's horizon was not broad enough. For a man who wants to rule the world, everywhere is his territory and everyone is his subject.

Alexander took the opposite attitude from Aristotle after he went to Persia. This is somehow sarcastic because what inspired Alexander's contrasting opinion from his teacher was exactly introduced by his teacher, who taught him Iliad and broadened his vision. For instance, he was not ashamed to exchange the head-dress which he the conqueror had so long worn, for that of the conquered Persians. What is more, when Alexander caught the wife and daughters of Darius, he treated them mildly and kindly. These women never heard anything that could disgrace them, but lived, as though guarded in sacred virgins' chambers, apart from the speech and sight of men. Alexander considered the mastery of himself a kinglier thing than the conquest of his enemies, and he never laid hands upon these women. Another example was that Alexander hired Persian soldiers to set up a new army, which aroused many disagreements from the Macedonians. He collected the Macedonians and announced that he intended to discharge from the army those who were useless for military service due to age or disability. Then, he called Persians 'the members of his family' and exchanged kisses with them.

After Alexander the Great's triumphant conquest, he immediately took integrated imperial measures, such as appointing a large number of Persians as courtiers, rearranging army, and moving the capital. In the Opis Banquet, Alexander prayed for the harmony and community of rule between the Macedonians and Persians. In Susa, he organized an unprecedented mass marriage, which was not only renowned for its grand scale and luxury, but also for that many bridegrooms and brides attending the wedding belong to different civilizations and ethnics. These all showed that he never treated the foreigners like plants or animals, and he had little tendency of racial discrimination since he was a kind of 'hybrid' himself.

Napoleon once said that if I had not been born Napoleon, I would have liked to have been born Alexander.' He greatly admired the outstanding political consciousness-the art that can win the favor of the people-of Alexander the Great. [7] Indeed, unlike Aristotle, Alexander possessed the wisdom of a politician who linked his political, economic and cultural goals with his military goals. He dressed himself up as a liberator: in Egypt, he became the son of Amon; in Persia, he even unfurled the banner of revenge for Darius III; in Bactria, he became the friend of the kings there and made them local governors; in Asia, he married Roxane-the daughter of a royal family. All these incidents displayed his wisdom and ingenuity as a politician. It was because of these strategies that his dominance was basically recognized by the people of the conquered areas. Although it was undeniable that he also savagely massacred many conquered areas, he had strong empathy and foresight. Even though he was arrogant, drunken, cruel, vindictive, and grossly superstitious, nobody could deny his greatness.

\section{CONCLUSION}

If people define Aristotle as a Greek in the era of city-state, then Alexander the Great is a Greek beyond the era of city-state. Different family background and disparate database caused the contradictions between these two characters. Alexander learned various things from his teacher, but he did not uncritically obey all those instructions. He realized that 'he could conquer a world empire from the back of his horse, but he could not rule it from the back of his horse'. From Egypt to 
the sea, Alexander the Great formed a consolidated bridge among the lands and people. He used his sturdy constitution, penetrating eyes, and empathetic heart to rule his kingdom.

In Iliad, Achilles' only weakness was captured, and he died from an arrow in his heel, but Alexander continued his unique epic in his own way. What he left behind was a 'silk road' before Zhang Qian's, a concept of world unification, a dream of exploring the unknown, and a possibility of cultural integration, much more than merely an ethereal myth or legend.

\section{REFERENCES}

[1] Rogers, G. (2005) Alexander, The Ambiguity of Greatness. Random House Trade Paperbacks, New York.

[2] Arrian. (2014) The Anabasis of Alexander. The Selwood Printing Works, London.

[3] Plutarch. (1919) The parallel lives. Loeb Classical edition, Cambridge.

[4] Aristotle. (1999) Nicomachean Ethics. Batoche books, Kitchener.

[5] Russel, B. (1945) The history of Western Philosophy. Simon and Schuster, New York

[6] Aristotle. (1999) Politics. Batoche books, Kitchener.

[7] The Project Gutenberg eBook. (2009) Alexander the Great. www.gutenberg.org 